Magomedov David Rasimovich, Lead Engineer Institute of Metallurgy and Ore Benefication Magistracy student at Satbayev University Almaty, the Republic of Kazakhstan E-mail:davidmag16@mail.ru ORCID ID: 0000-0001-7216-2349 Koizhanova Aigul Kaiyrgel'dyevna, head of laboratory Institute of Metallurgy and Ore Benefication Almaty, the Republic of Kazakhstan E-mail: aigul_koizhan@mail.ru ORCID ID: 0000-0001-9358-3193

\title{
OXIDATIVE LEACHING OF GOLD FROM SORPTION TAILINGS USING SURFACTANTS AND OXIDIZING AGENTS
}

\begin{abstract}
The article presents the results of researches on the processing of gold-bearing old sorption tailings. The tailings sample contains $4.75 \mathrm{~g} /$ ton of gold and is a refractory raw material, with a predominance of sulfide minerals - arsenopyrite and pyrite. During the gold extraction experiments, the effect of oxidizing agents, surfactants, and other chemicals and combinations on the leaching process was investigated.
\end{abstract}

Key words: Oxidative leaching of gold, surfactants, sorption tailings, sulphide minerals.

In the process of industrial processing of gold-bearing mineral raw materials, almost all the processed rock mass is concentrated in tailing dumps, and over the years of the gold mining enterprises activity, multi-million tailing dumps accumulate. Such heaps of past gold mining can be represented by small materials: gravity tails, amalgamation, flotation, cyanation cakes, cinders, etc. The gold content in tailing heaps of previous years may exceed the content in current ores $[1,9,10]$.

The solution to the problem of re-mining gold from mining waste and ore dressing is hampered by the lack of research in the field of technologies for extracting gold from low-grade raw materials. The issues of obtaining gold from the accumulated waste of mining and processing of ores at the final stage of the development of gold deposits form an independent major problem of mining science and practice. In accordance with the task set, the laboratory carried out the main stages: the physicochemical properties of the old sorption tailings of a gold recovery plant were studied, and research was carried out on the integrated processing of goldbearing raw materials of a gold recovery plant. For research purposes, representative samples of the stale tailings of the gold extraction plant of the Vasilkovskoye field of AltyntauKokshetau LLP were used.

The X-ray fluorescence analysis of the sample of sorption sorbed tailings (table 1) showed a significant content of such elements as oxygen (31.675\%), arsenic (17.15\%), quartz (15.677\%), iron $(15.109 \%)$ and sulfur $(11.877 \%)$. The predominance of these elements in the sample is characteristic of such minerals as quartz, arsenopyrite, and pyrite.

Table 1 - Results of X-ray fluorescence analysis

\begin{tabular}{|c|c|c|c|c|c|c|c|c|c|}
\hline Element & $\%$ & $\begin{array}{c}\text { Elemen } \\
\mathrm{t}\end{array}$ & $\%$ & $\begin{array}{c}\text { Elemen } \\
\mathrm{t}\end{array}$ & $\%$ & $\begin{array}{c}\text { Elemen } \\
\mathrm{t}\end{array}$ & $\%$ & $\begin{array}{c}\text { Elemen } \\
\mathrm{t}\end{array}$ & $\%$ \\
\hline $\mathrm{O}$ & 31.675 & $\mathrm{Fe}$ & 15.109 & $\mathrm{P}$ & 0.034 & $\mathrm{Ca}$ & 1.71 & $\mathrm{Sr}$ & 0.007 \\
\hline
\end{tabular}

Metallurgy - leaching of gold
Materials of International Practical Internet Conference "Challenges of Science" 


\begin{tabular}{|l|l|l|l|c|c|c|c|c|l|}
\hline $\mathrm{Na}$ & 0.821 & $\mathrm{Co}$ & 0.04 & $\mathrm{~S}$ & 11.877 & $\mathrm{Ti}$ & 0.103 & $\mathrm{Zr}$ & 0.012 \\
\hline $\mathrm{Al}$ & 4.477 & $\mathrm{Cu}$ & 0.115 & $\mathrm{Cl}$ & 0.048 & $\mathrm{As}$ & 17.15 & $\mathrm{Sb}$ & 0.027 \\
\hline $\mathrm{Si}$ & 15.677 & $\mathrm{Zn}$ & 0.006 & $\mathrm{~K}$ & 1.00 & $\mathrm{Rb}$ & 0.006 & $\mathrm{Bi}$ & 0.065 \\
\hline
\end{tabular}

X-ray phase analysis of stale sorption tailings (Table 2), in full accordance with X-ray fluorescent analysis, showed a significant amount of arsenopyrite (29.2\%), quartz (16.5\%), pyrite $(10.3 \%)$ and other minerals.

Table 2 - X-ray phase analysis of a sample of old tails

\begin{tabular}{|l|l|c|}
\hline Compound Name & Formula & S-Q \\
\hline Arsenopyrite & $\mathrm{FeAsS}$ & 29.2 \\
\hline Quartz, syn & $\mathrm{SiO}_{2}$ & 16.5 \\
\hline Pyrite & $\mathrm{FeS}_{2}$ & 10.3 \\
\hline Albite & $\mathrm{Na}_{2}\left(\mathrm{AlSi}_{3} \mathrm{O}_{8}\right)$ & 9.6 \\
\hline Muscovite 2M1 & $\mathrm{KAl}_{3} \mathrm{Si}_{3} \mathrm{O} 10(\mathrm{OH})_{2}$ & 9.3 \\
\hline Tremolite & $\left(\mathrm{Ca}, \mathrm{Na}_{2}, \mathrm{Fe}\right)_{2} \mathrm{Mg}_{5} \mathrm{Si}_{8} \mathrm{O}_{22}(\mathrm{OH})_{2}$ & 8.3 \\
\hline Clinochlore & $(\mathrm{Mg}, \mathrm{Fe})_{5} \mathrm{Al}_{2}\left(\mathrm{Si}_{3} \mathrm{Al}_{2} \mathrm{O}_{10}(\mathrm{OH})_{8}\right.$ & 6.4 \\
\hline Calcite & $\mathrm{Ca}\left(\mathrm{CO}_{3}\right)$ & 5.6 \\
\hline Microcline, intermediate & $\mathrm{KAlSi}_{3} \mathrm{O}_{8}$ & 4.6 \\
\hline
\end{tabular}

During the chemical analysis, the gold content was found to be $4.75 \mathrm{~g} / \mathrm{t}$, silver $-0.92 \mathrm{~g} / \mathrm{t}$, iron $-20.9 \%$, sulfur $-12.72 \%$, as well as minor amounts of copper $(0.04 \%)$ and zinc $(0.005 \%)$. Chemical analysis of samples of old sorption tailings is presented in Table 3.

Table 3 - The chemical composition of the initial old sorption tailings

\begin{tabular}{|l|l|l|l|l|l|}
\hline $\mathrm{Au} \Gamma / \mathrm{T}$ & $\mathrm{Ag} \Gamma / \mathrm{T}$ & $\mathrm{Fe}, \%$ & $\mathrm{~S}, \%$ & $\mathrm{Cu}, \%$ & $\mathrm{Zn}, \%$ \\
\hline 4.75 & 0.92 & 20.9 & 12.72 & 0.04 & 0.005 \\
\hline
\end{tabular}

In order to determine the forms of finding gold in the sample of the old sorption tailings, a rational phase analysis was performed, the results of which are presented in Table 4.

Table 4 - Results of rational phase analysis

\begin{tabular}{|l|c|c|}
\hline \multicolumn{1}{|c|}{ Gold Forms } & Au content, $\mathrm{g} / \mathrm{t}$ & $\mathrm{Au} \%$ distribution \\
\hline Fine dispersed Native Gold & 0.35 & 7.37 \\
\hline Visible Native Gold & 0.35 & 7.37 \\
\hline Gold associated with the crystal lattice of the mineral & 3.9 & 82.11 \\
\hline Gold in quartz, insoluble in $3 \mathrm{HCl}-\mathrm{HNO}_{3}$ & 0.15 & 3.15 \\
\hline Total gold & 4.75 & 100.0 \\
\hline
\end{tabular}

As can be seen from the rational phase analysis, gold is mainly associated with the crystal lattice of the mineral $-82.11 \%$, fine and visible native gold is $7.37 \%$ each, and only $3.15 \%$ is contained in quartz.

The sample of old tailings is a gold-bearing deposit, in the form of fine-grained bulk material, black. The grains in the briquette are very small, measuring in millimeters and up to $0.01-0.09-0.1 \mathrm{~mm}$. Most of the fragments of irregularly shaped grains. Grains are usually free, but are also found in the form of inclusions in the non-metallic mass. According to mineralogical and X-ray phase analyzes, rock-forming minerals are represented by arsenopyrite, pyrite, quartz, muscovite, potassium feldspar, albite, and calcite. Arsenopyrite (figure 1, 2, 3), which is more

\section{Metallurgy - leaching of gold}


than $30 \%$, prevails; non-ores part forms clusters as one grain. Pyrite (Figure 2) is mainly found in intergrowth with non-ores minerals.

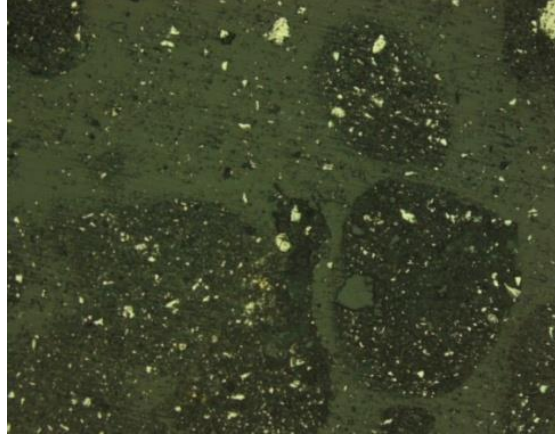

Figure 1 - Sample tails. Zoom X 100

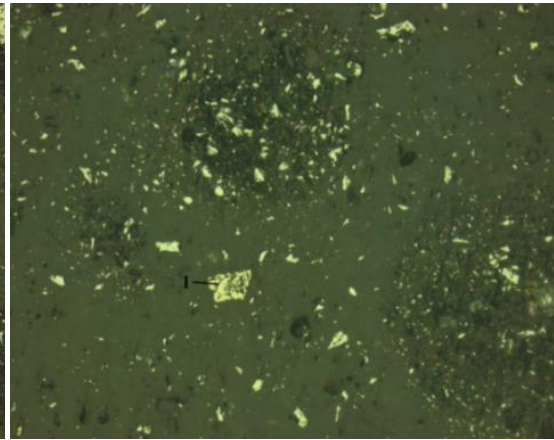

Figure 2 - Sample tails. Zoom X 200. 1-pyrite

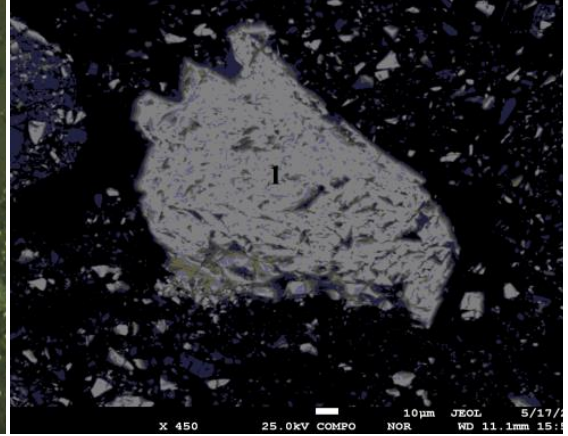

Figure 3 - Sample tails. Zoom X 450. COMPO mode, 1 - arsenopyrite

Cubic syngony, color silver-white, octahedral crystal appearance. Under the microscope, a thin myrmekitic fusion of native gold and bismuth is established, which is the product of the decomposition of the intermetallic compound $\mathrm{Au}_{2} \mathrm{Bi}$.

After researching the physicochemical properties and mineralogical composition, samples of old tailings were prepared for experiments on the extraction of gold by the method of agitation leaching. Experiments on leaching of gold from old tailings were carried out on a sample with the initial content of $4.75 \mathrm{~g} / \mathrm{t}$. Before starting the experiments, various combinations of leaching reagents were studied, including the use of surface-active substances, oxidizing agents, additional pulp grinding, etc.

Thus, surface-active substances (surfactants) increase the rate of oxidation of sulfides in the initial period, reduce the incubation period of the beginning of their oxidation (lagphase). However, the completeness of the process is almost unchanged. It is recommended to add to the solution $0.0001-0.05 \%$ of surfactants based on polyexyethylene mono-laurates, palmats, stearates, oleates [2]. Sulfonol was used as one of the types of surfactants (alkyl benzene sulfonate, a mixture of sodium benzene sulfonic acid sodium salt isomers, with the general formula $\mathrm{R}-\mathrm{C}_{6} \mathrm{H}_{4} \mathrm{NaO}_{3} \mathrm{~S}$, where $\mathrm{R}$ is the radical corresponding to the general formula $\mathrm{C}_{n} \mathrm{H}_{2 n}+1$, where $n=14-18$ - figure 4$)$.

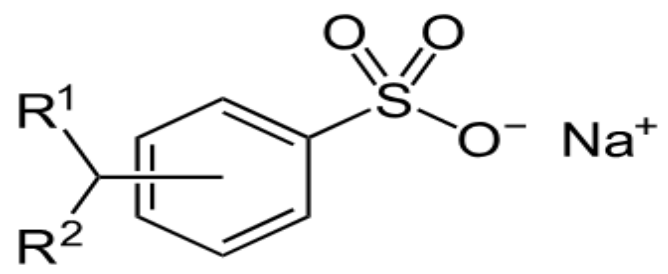

\section{Figure 4 - The structure of alkyl benzene sulfonate}

Considering the fact that $82.11 \%$ of gold is associated with the crystal lattice of minerals, it was also decided to work out variants using oxidizing agents in order to decomposition mainly sulphide minerals such as pyrite and arsenopyrite [3]. In sulfide ores, the main minerals of iron are pyrite, marcasite, pyrrhotite. The oxidation of pyrite occurs as follows:

$$
2 \mathrm{FeS}_{2}+7 \mathrm{O}_{2}+2 \mathrm{H}_{2} \mathrm{O} \rightarrow>2 \mathrm{FeSO}_{4}+2 \mathrm{H}_{2} \mathrm{SO}_{4}
$$

Metallurgy - leaching of gold
Materials of International Practical Internet Conference

"Challenges of Science" 
The sulfate $\mathrm{Fe}^{3+}$ formed during the oxidation of pyrite, in turn, affects pyrite, which results in the release of sulfur: $\mathrm{FeS}_{2}+\mathrm{Fe}_{2}\left(\mathrm{SO}_{4}\right)_{3}=3 \mathrm{FeSO}_{4}+2 \mathrm{~S}$.

Sulfuric acid or $\mathrm{SO}_{2}$ is formed by sulfur oxidation. Pyrrhotite is the most easily degradable $\mathrm{FeS}+2 \mathrm{O}_{2}=\mathrm{FeSO}_{4}$ sulfide plus a small amount of free sulfuric acid. Ferrous sulphate of iron $\mathrm{FeSO}_{4}$ further undergoes a change to $\mathrm{Fe}_{2}\left(\mathrm{SO}_{4}\right)_{3}$, and the latter, hydrolyzing, gives iron hydroxide and sulfuric acid, i.e. the process proceeds similarly to the oxidation of pyrite. The oxidation of arsenopyrite proceeds in the same way as pyrite, and as a result, the scorodite is formed:

$$
2 \mathrm{FeAsS}+6 \mathrm{H}_{2} \mathrm{O}+7 \mathrm{O}_{2}=2\left[\mathrm{FeAsO}_{4} \times 2 \mathrm{H}_{2} \mathrm{O}\right]+2 \mathrm{H}_{2} \mathrm{SO}_{4}
$$

The thin impregnation of gold is the most common cause of the tenacity of gold ores. For their processing, three-stage grinding schemes are used, giving a very fine grinding (90-95\% of the class $-0.04 \mathrm{~mm}$ ). Cyaning such a finely ground material makes it possible, as a rule, to produce tailings with a low gold content [5].

In addition to direct cyanidation, oxidation with calcium hypochlorite [6] and cyanidation with surfactants, leaching options were used with pre-treatment with ammonium fluoride to destroy the structure of quartz, sodium sulfate for preliminary extraction of arsenic, water and acid washing, the use of a bacterial solution [7] and thiourea. A total of 15 leaching options were tested.

The solid cakes obtained after leaching were sent for analysis to determine the residual gold content. According to the results of the analysis, a balance was drawn up and gold extraction was calculated for each variant. The results of the extraction of gold from old tailings sorption are presented in table 5.

Table 5 - gold leaching results with different reagent variants and parameters

\begin{tabular}{|c|c|c|c|}
\hline № & Additional conditions / reagents & $\mathrm{Au}$ in cake, $\mathrm{g} / \mathrm{t}$ & $\mathrm{EAu}, \%$ \\
\hline 1 & only $\mathrm{NaCN}-0,1 \%$ (control) & 3.84 & 19.16 \\
\hline 2 & $\mathrm{H}_{2} \mathrm{SO}_{4} 2 \%, \mathrm{NaCN}-0,1 \%$ & 4.22 & 11.16 \\
\hline 3 & $\mathrm{H}_{2} \mathrm{SO}_{4} 2 \%, \mathrm{NH}_{4} \mathrm{~F} 0,5 \mathrm{~g}, \mathrm{NaCN}-0,1 \%$ & 3.88 & 18.32 \\
\hline 4 & $\mathrm{Ca}(\mathrm{ClO})_{2}-1 \mathrm{~g}, \mathrm{NaCN}-0,1 \%$ & 3.73 & 21.47 \\
\hline 5 & $\mathrm{H}_{2} \mathrm{SO}_{4} 2 \%, \mathrm{Na}_{2} \mathrm{SO}_{4}-3,5 \mathrm{~g}, \mathrm{NH}_{4} \mathrm{~F}-0,6 \mathrm{~g}, \mathrm{NaCN}-0,1 \%$ & 3.8 & 20.00 \\
\hline 6 & $\mathrm{H}_{2} \mathrm{O}$ washing, $\mathrm{H}_{2} \mathrm{SO}_{4} 3 \%, \mathrm{CS}\left(\mathrm{NH}_{2}\right)_{2}-1 \mathrm{~g}$ & 5.58 & - \\
\hline 7 & $\mathrm{H}_{2} \mathrm{O}$ washing, $\mathrm{H}_{2} \mathrm{SO}_{4} 3 \%$, bacterial solution, $\mathrm{CS}\left(\mathrm{NH}_{2}\right)_{2}-1 \mathrm{~g}$ & 3.95 & 16,84 \\
\hline 8 & $\mathrm{NaCN}-0,1 \%$, Surfactant sulfanol $-0.5 \mathrm{~g}$ & 2.9 & 38.95 \\
\hline 9 & $\mathrm{NaCN}-0,1 \%$, Surfactant sodium stearate $-3.5 \mathrm{~g}$ & 3.2 & 32.63 \\
\hline 10 & $\mathrm{NaCN}-0,1 \%$, anionic surfactant $-2.5 \mathrm{~g}$ & 3.37 & 29.05 \\
\hline 11 & $\mathrm{H}_{2} \mathrm{SO}_{4} 2 \%+. \mathrm{NaCN}-0,1 \%,+$ sodium stearate $3.5 \mathrm{~g}$ & 2.85 & 40.0 \\
\hline 12 & $\mathrm{H}_{2} \mathrm{SO}_{4} 2 \%+. \mathrm{NaCN}-0,1 \%,+$ sulfanol $1 \mathrm{~g}$ & 2.71 & 42.95 \\
\hline 13 & Grinding to $0.02 \mathrm{~mm}+\mathrm{NaCN}-0,1 \%$ & 2.64 & 44.42 \\
\hline 14 & Grinding to $0.02 \mathrm{~mm}+\mathrm{NaCN}-0,1 \%+$ sulfanol $1 \mathrm{~g}$ & 2.06 & 56.63 \\
\hline 15 & Grinding to $0.02 \mathrm{~mm}+\mathrm{NaCN}-0,1 \%+$ sodium stearate $3.5 \mathrm{~g}$ & 2.35 & 50.52 \\
\hline
\end{tabular}

As can be seen from the table above, the extraction of gold from these old sorption tailings with the use of various oxidation activators does not give effective results. Direct cyanidation can extract only $19.16 \%$. Pre-washing with sulfuric acid, neutralization of the acidic medium and subsequent cyanidation shows the result even worse than with direct cyanidation -

Metallurgy - leaching of gold 
$11.16 \%$. The low extraction in the first two variants is due to the presence of sulfur in a nonoxidized form as sulphides, as well as its possible yield in pure molecular form. The most frequent case of high consumption of sodium cyanide is the presence in the ores or concentrates of iron sulfide minerals (also called pyrite) pyrite, marcasite and pyrrhotite. Most of the fresh iron sulphide minerals interact very slowly and weakly with sodium cyanide. But it is enough for these sulphides to lie down in the wet state in the air, as the process of their decomposition is already beginning. Especially easy is the oxidation of crushed pyrites due to the huge increase in their surface. At the same time, pyrrhotines are most rapidly oxidized. The latter begin to decompose from slaughter and are especially vigorously oxidized during grinding with the elimination of elemental sulfur, which reacts with cyanide by the reaction: $\mathrm{NaCN}+\mathrm{S}=\mathrm{NaCNS}$ with the formation of rodanum sodium, not dissolving gold. Sulfur prevents the dissolution of gold, absorbing oxygen. Even a small amount of pyrrhotite in the ore can cause low gold recovery and such a high consumption of cyanide that the treatment of ores with cyanidation becomes uneconomical [8]. The use of calcium hypochlorite, as an oxidizing agent in the 4th variant, slightly increased the degree of extraction to $21.47 \%$. The use of surfactants contributed to a more significant increase in the degree of extraction, in particular: using anionic surfactants, the extraction amounted to 29.05 , with sodium stearate $-32.63 \%$, with sulfanol $-38.95 \%$. Preacid washing, followed by the use of surfactants and cyanidation, showed extraction levels of $40.0 \%$ (with sodium stearate) and $42.95 \%$ (with sulfanol). Maximum extraction rates were achieved with fine grinding in a bead mill to a particle size class of $0.02 \mathrm{~mm}$. Direct cyanidation of the finely ground sample gave a result of $44.42 \%$ gold recovery. The use of sodium stearate during cyanidation of the sample with a particle size of $-0.02 \mathrm{~mm}$ increased extraction to $50.52 \%$, and with sulfonol increased to $56.63 \%$. Figure 5 shows a histogram comparing the experimental leaching options for gold from old sorption tailings.

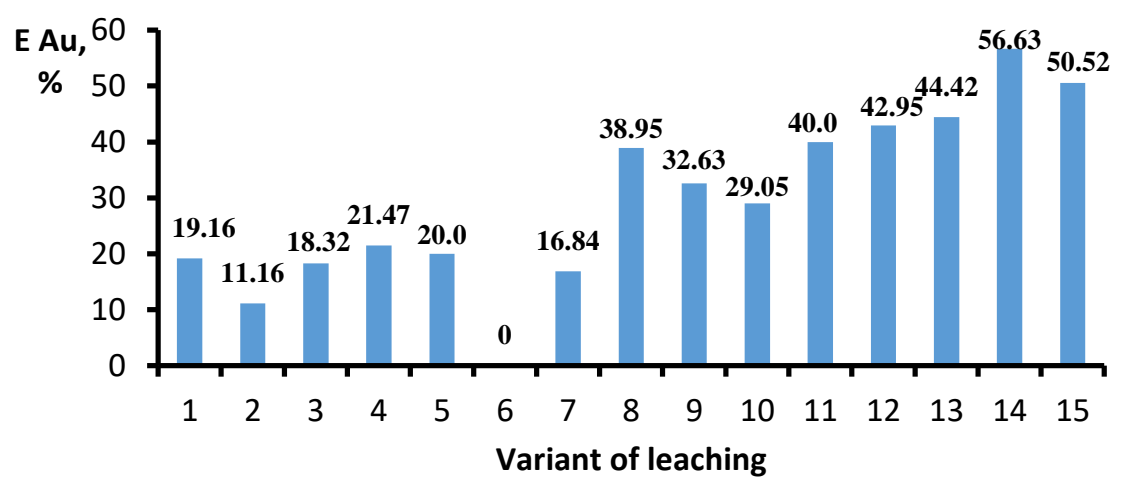

\section{Figure 5 - comparison of the effectiveness of experimental variants of gold extraction.}

Thus, it was confirmed that for the effective extraction of gold from this type of raw material - old sorption tailings with a high content of arsenopyrite and pyrite, more fine grinding to $-0.02 \mathrm{~mm}$ is necessary. However, given the fact that for such production conditions such fine grinding is not feasible in most cases, it is possible to consider options involving the chemical decomposition of gold-containing sulphide minerals. Experiments have shown that in the process of oxidative leaching, it is necessary to oxidize not only gold-containing sulphides, but also released molecular sulfur, which can reduce the efficiency of cyanidation. Therefore, for leaching gold from this sample of old tailings, a processing scheme may be recommended that includes preliminary washing with sulfuric acid, followed by surfactant treatment with sulfanol,

Metallurgy - leaching of gold
Materials of International Practical Internet Conference "Challenges of Science" 
then, after achieving complete oxidation of sulfide minerals and released sulfur, cyanide leaching.

\section{REFERENCES}

1. Dementiev V.E., Druzhina G.Ya., Gudkov S.S. Heap leaching of gold and silver. Irkutsk: Irgiredmet OJSC, 2004. P 76-77.

2. Luganov V.A. Lectures on the subject "Special chapters of the theory of metallurgical processes." Satbayev University. 2018. lecture 15.

3. Kenzhaliyev B.K., Berkinbayeva A.N., Dosymbayeva Z.D., Sharipov R.Kh. Extraction Of Non -Ferrous And Noble Metals From Mill Tailing By Solutions In The Presence Of Oxidizing Agents International Journal of Engineering and Applied Sciences (IJEAS)ISSN: 2394-3661, Volume-4, Issue-8, August2017. P 93-95.

4. Hypergenic changes in endogenous ore deposits, materials from site: http://biofile.ru/geo/15203.html

5. Vasilyeva A.V., Dementieva N.A., Koblov A.Yu. Extraction of fine gold by centrifugal devices of various modifications. Zolotodobycha (Gold mining), №76, March, 2005

6. Bagdaulet Kenzhaliyev, А.К. Койжанова, Г.Ж. Абдыкирова, Э.М. Камалов, Д.Р. Магомедов, Выщелачивание золотосодержащего сырья с использованием окислителя. Международная научно-практическая конференция "Эффективные технологии производства цветных, редких и благородных металлов". September 2018, https://doi.org/10.31643/2018-7.14

7. Kenzhaliyev Bagdaulet, Berkinbayeva Ainur, Recovery of precious and non-ferrous metals from the rebellious complex of mineral raw materials/ Mining \& Metallurgy Engineering Bor No.3, 2015 / DOI:10.5937/MMEB1503109B. P. 109.

8. Barchenkov V.V. On the irretrievable loss of cyanide in the process of dissolution of gold and measures to reduce it CJSC "IIS Minerals" Zolotodobycha (Gold mining), No. 187, June, 2014.

9. Zhapbasbayev, U., Ramazanova, G., Kenzhaliev, B., Sattinova, Z., Shakhov, S. Experimental and calculated data of the beryllium oxide slurry solidification. (2016) Applied Thermal Engineering, 6, pp. 593-599. doi:

10.1016/j.applthermaleng.2015.11.114 http://www.journals.elsevier.com/appliedthermal-engineering/

10. Bagdaulet KenzhaliyevSergey KvyatkovskiySultanbek Kozhakhmetov, L V Sokolovskaya, A S Semenova, Depletion of waste slag of balkhash copper smelter. Journal: Kompleksnoe ispol'zovanie mineral'nogo syr'â. August 2018. DOI: $10.31643 / 2018 / 6445.16$ 